Lesya Lymar,

PhD (Candidate of Psychological Sciences), senior lecturer, Foreign Languages Department, Bogomolets National Medical University, 13, Shevchenko Boulevard, Kyiv, Ukraine

\title{
CHARACTERISTICS OF THE REGULATION COMPONENT OF SCHOOL MEDICAL PERSONNEL'S READINESS FOR INTERACTION WITH CHILDREN
}

The article is dedicated to analysis of characteristics of regulation component of the school medical personnel's readiness for interaction with children, studied with the Medical university students who worked with children in schools or summer camps. The author supposes that the predisposing factors for the successful functioning of the medical personnel at school depend on the establishing of the emotional contact with children, which is stipulated by the readiness for the productive interaction. The article contains the description of the regulation component, specifies methods used for its detection in young medical specialists and the subsequent data analysis. According to the survey of 334 medical students, just one third of them showed the high level of psychological readiness for interaction with children, $9.6 \%$ of the surveyed demonstrated the low level. The author analyses the results obtained and gives recommendations on necessary correction.

Keywords: school medical personnel, readiness, regulation, interaction, children.

Medical personnel of secondary schools perform many important functions. The prerequisites for the successful functioning of the medical personnel in school involve not only curative and preventive duties, but, first of all, establishing the emotional contact with children, which is characterized by doctors and nurses' readiness for productive interaction. Detection of characteristics of the school medical personnel's readiness for interaction with children is important for defining the factors that may prevent productive interaction of the physicians or nurses with children and their subsequent correction. It is particularly important to detect the level of medical students' readiness for the medical productive interaction with children, in order to correct it in the initial stages of their professional development.

Many Ukrainian and foreign psychologists and deontologists have studied the problem of medical personnel's readiness for interaction with patients, children in particular. O. Kobzar has defined three basic characteristics which are required for the physician's successful work with adults and children: well-formed professional characteristics (specialist's readiness for supervising children and interacting with them, professional knowledge and skills and his/her general mindset) [3]. Unfortunately, within the deontological cycle taught in medical colleges and schools, such subjects as children psychology, pedagogy and pediatric deontology are not studied to the extent required (maximum 2-4 hours within the general course of deontology) [6]. I. Vitenko defined the structure of physician's readiness for supervising a patient as the one containing his/her psychological readiness, ethical readiness and communication style, particularly while dealing with small patients [9]. Due to the low salary and staff position of a nurse, only certified nurses, feldshers or the senior course medical students are usually employed in secondary schools. As the appropriate course of child psychology is not taught in medical colleges and schools, this may present a significant prob- lem resulting in unproductive interaction of medical personnel with children.

The author analyzed the structure of the physician's readiness for productive interaction with a patient, and, having compared the physician's readiness for interaction with an adult patient to his/her readiness for interaction with a child patient, defined common components of the readiness: motivation, regulation, emotional, cognitive and communicative components [4].

The aim of the study is to detect the main components of the school medical personnel's regulation component of readiness for interaction with children, to choose proper methods for its detection and to perform empirical study of the component development in the medical personnel dealing with children in schools or summer camps with the subsequent recommendations on correction if necessary.

The regulation component of the medical specialists' readiness is represented by the combination of knowledge and practical skills required for the productive interaction with children. The specialist must understand all the psychological processes that may appear during his/her interaction with children distinctly, follow his/her own psychoemotional states and control him-/herself when supervising child patient. In the author's opinion, the regulation component of physician's readiness for productive interaction with children must include the following skills: analyzing his/her own behavior, choosing the best strategies of coping with complicated situations, the ability for flexible choice of the best behavioral patterns depending on the needs of the children.

To detect the medical personnel's regulation component of psychological readiness for interaction with children, we chose the following methods: method of selfcontrol diagnostics by M. Snider [5], method of behavioral style diagnostics by T. Thomas, adapted by N. Grishina 
[7], and S. Hobfoll's method "Strategies of Coping with Stress" [2].

The method of estimation of self-control by M. Snider provides us with the opportunity to detect communicative control expressed by the medical personnel. The respondents with the high communicative control level continuously mind their own behavior and they can detect their own emotional conditions easily. At the same time, they experience difficulties in expressing their spontaneous feelings and feel anxiety in unpredictable situations. The surveyed students with low communicative control level are more open, their internal "Self"-structure is developed better, and they do not consider it necessary to change themselves according to the situation. The method contains ten sentences that describe responses to some situations. The surveyed are offered to estimate these ten sentences. We suppose that both the high and the low level of self-control may complicate interaction of a physician with a child patient.

The method by K. Thomas adapted by N. Grishina intended to detecting the main behavioral styles expressed by physicians in conflict interaction, particularly with children, relates to the two-dimensional conflict management model, where one vector is a cooperation (which is respondent's consideration for others' interests), and another vector is his/her acts aimed at defending his/her own interests. The author defines such ways of the conflict management as: competition, when the party aims to reach the goals and hamper the interests of the other party; victim strategy, when the party neglects one's own interests for the benefit of another participant; compromise, when both participants may partly satisfy their requirements; avoiding as the tendency for absence of cooperation, when no party reaches the required goals; cooperation, when both participants satisfy their requirements completely.

Another method used in our survey was S. Hobfoll's method of detecting strategies of coping with stressful situations [2], which provides with the opportunity of detecting the behavioral strategies in stressful and complicated situations: assertive actions, seeking for social contact, careful actions, impulsive action, contact avoiding, asocial or aggressive actions. Due to S. Hobfoll's concept, there have been defined three vectors of the intrapersonal problematic interaction: prosocial-asocial, active-passive, and direct-indirect (manipulative) behavior. According to the presence of personal resources and due to the theory of stress and coping [2], a personality chooses adaptive or non-adaptive coping strategies. The adaptive strategies are: assertive actions, social contact, seeking for social support, and these actions are aimed at coping with the problem situations, particularly when dealing with children. In the non-adaptive strategies such as aggressive actions, asocial actions, avoiding, etc., a personality may express social hesitation or negativism towards the environment. The results interpretation made it possible to conclude that the level of the strategy constructiveness and behavioral model affect the process of dealing with the professional conflicts with the children. We suppose that the most acceptable behavioral pattern in case of complicated interaction with the children is an assertive strategy as such behavior prevents conflicts in the process of interaction and in the conflict situations it helps to cope with the problems.

Totally, according to the survey, the high level of the regulation component was established in case of the present medium self-control expression, flexible behavioral pattern expressed in complicated interaction and prevailing assertive behavioral strategies. The low level of the regulation component was established in case of the present low level of self-control expression, "competition" behavioral pattern expressed in complicated interaction and prevailing destructive behavioral strategies. All other combinations of the results were attributed to the medium level of the regulation component of readiness for physician's interaction with children.

Totally, the study involved 334 students of Bogomolets National Medical University. 32\% of the surveyed had experience of being employed as medical personnel (nurses) in secondary schools or in summer camps. For this reason, the author considered it possible to regard them as school medical personnel interacting with children: if any unfavorable characteristics are discovered during the study at medical school, it will be easier to correct them in students, rather than in already "mature" medical professionals.

The detection of the medical personnel's self-control levels according to M. Snider's method showed that the optimum medium self-control level was peculiar to most of the surveyed (69.3\%) (tab.1).

Table 1.

Levels of medical students' self-control

\begin{tabular}{|c|c|}
\hline Levels & Amount of the surveyed, \% \\
\hline low & 20.5 \\
\hline medium & 69.3 \\
\hline high & 10.2 \\
\hline
\end{tabular}

One third of the respondents expressed low (20.5\%) or high $(10.2 \%)$ levels of self-control. We consider low self-control level to be the most conflict-provoking in communication with children as in this case the surveyed does not care about other's perception of his/her actions and does not aim to adapt them according to the social expectation, which is impermissible while working with children. In case of high communicative self-control expression, a person changes his/her behavior depending on the circumstances, in order to impress others, which is also harmful for diagnosing and treating the children. 
The analysis of the behavioral patterns expressed in complicated (conflict) situations showed that a compro- mise is a prevailing behavioral strategy characterizing the surveyed students (tab. 2).

Table 2.

Behavioral patterns expressed by the medical personnel in complicated (conflict) situations

\begin{tabular}{|c|c|}
\hline Behavioral pattern & Points, mean average \\
\hline compromise & 7.8 \\
\hline adaptation & 6.3 \\
\hline avoiding & 5.7 \\
\hline competition & 5.2 \\
\hline cooperation & 5.1 \\
\hline
\end{tabular}

The second position is held by adaptation and avoiding; the prevalence of these styles points out that physicians are prone to neglect their own interests for the benefit of other people, children in particular.

On the other hand, cooperation as a key behavioral strategy expressed under the complicated interaction takes up the second position, which may indicate some difficulties in partner interaction of physicians with children patients. Generally, the tendency towards compromise expressed by the surveyed physicians was confirmed by prevailing behavioral style under the conflict circumstances (calculated in percent) (tab. 3 ).
$14.5 \%$ of the surveyed aim to choose competition in their interaction. So, these respondents may interact with children unproductively, with subsequent conflicts, which may lead to misdiagnosis, late disease prevention and numerous complications of treatment.

One fifth of the surveyed chose avoiding (11.9\%) and adaptation (10.6\%) as basic behavioral strategies in complicated interaction situations. Such position may lead to the passive conflict interaction with children, while attempts to decrease tension in such relations lead to even more destructive consequences, as the problem cannot be solved with the prevailing strategy.

Table 3.

Prevailing behavioral strategies expressed by the medical students in complicated interaction (conflict interaction).

\begin{tabular}{|c|c|}
\hline Behavioral strategies & Amount of the surveyed, $\%$ \\
\hline compromise & 44.2 \\
\hline competition & 14.5 \\
\hline avoiding & 11.9 \\
\hline adaptation & 10.6 \\
\hline cooperation & 9.4 \\
\hline flexible style & 9.4 \\
\hline
\end{tabular}

$14.5 \%$ of the surveyed students chose competitive strategy, consequently, this group requires correction aimed at improvement of their professional characteristics. One fifth of the surveyed chose avoiding (11.9\%) and adaptation $(10.6 \%)$ as key behavioral strategies in conflict interaction with patients. Such attitude may cause passive conflict-provoking behavior when their tendency to avoid or decrease the tension in relations will lead to even more destructive consequences, as the problem will not be solved with the use of such a strategy, especially dealing with children.

Collaboration as the most acceptable way of complicated interaction management was chosen by $9.4 \%$ of the respondents. The author assumes that the reason is that the medical personnel employed in schools do not always have enough time and other resources necessary for solving the problem, or they do not have sufficient level of interactional competence to use collaboration strategy more often.

The flexible (and, in the author's opinion, the most appropriate) behavioral style was detected just in $9.4 \%$ of all the surveyed students.
The last method used for the regulation component detection was S. Hobbfol's method of identifying the strategies of coping with stressful situations (tab. 4).

The results represented in the table 4 show that under the stressful circumstances the surveyed students choose the social responding strategies (acquiring social contacts, seeking for social support). According to S. Hobfoll's concept, such a tendency corresponds to pro-social coping with the stressful situations.

The tendency towards assertive actions is not significant within the offered strategies, and the surveyed medical students prefer careful actions and manipulation. A positive fact is that aggressive, asocial, impulsive actions and avoiding take up last positions in the list, as these behavioral models intensify negative emotions and complicate interaction of a physician or a nurse with schoolchildren considerably.

The factor analysis of stress coping strategies revealed four factors represented in the table 5 . The first factor (20.9\% of total dispersion) included asocial actions (0.816), indirect actions (0.733), aggressive actions (0.639), that is why, it was classified as "Destructive stress coping strategies". The second factor $(18.3 \%$ of 
total dispersion) was made up by acquiring social contact (0.847) and seeking for social support (0.839), so it was defined as "Social stress coping strategies". The third factor (13.5\% of total dispersion) was made up by such strategies as careful actions (0.757) and assertive actions
(0.600), so it was called "Assertive stress coping strategies". The fourth factor (12.4\% of total dispersion) included avoiding (0.751) and impulsive actions (0.641), so it was classified as "Impulsive-avoiding stress coping strategies".

Strategies of coping with stressful situations, expressed by medical students.

\begin{tabular}{|c|c|}
\hline Strategies & Point, mean average \\
\hline acquiring social contact & 22.8 \\
\hline seeking for social support & 22.5 \\
\hline careful actions & 21.3 \\
\hline indirect actions & 20.1 \\
\hline assertive actions & 19.9 \\
\hline aggressive actions & 19.6 \\
\hline impulsive actions & 18.6 \\
\hline asocial actions & 17.3 \\
\hline avoiding & 17.3 \\
\hline
\end{tabular}

The cluster analysis conducted after the factor analysis made it possible to classify all the respondents into 5 groups according to the prevailing stress coping strategy, which is shown in the table 5.

Table 4 .

Groups of respondents according to the prevailing stress coping strategy.

\begin{tabular}{|c|c|}
\hline Groups of the surveyed & Amount of the surveyed, \% \\
\hline assertive & 38.4 \\
\hline social & 17.1 \\
\hline destructive & 14.0 \\
\hline impulsive avoiding & 17.7 \\
\hline problem & 12.8 \\
\hline
\end{tabular}

The first cluster "Assertive respondents" (38.4\%) was represented by the students who preferred mostly assertive actions of coping with stress. They can cope with difficult situations using various cognitive and behavioral experience on their own, without harm to the others, and this group is the most suitable for employment in schools. The second cluster "Social respondents" $(17.1 \%)$ was represented by the students who chose informational, subjective and emotional support of other people in stressful situations. The third cluster "Destructive respondents" (14.0\%) was represented by those students who expressed hostility in relations with other people as they preferred asocial strategies of stress coping. Using such a behavioral pattern, a personality may ignore social standards, preferring just his/her own interests, expressing irritation and aggression. The fourth cluster "Impulsive avoiding respondents" (17.7\%) included the students who ignored problems consciously, trying to avoid unfortunate situations, keeping to the intuitive behavioral pattern. The fifth cluster "Problem respondents" $(12.8 \%)$ included the surveyed who chose careful actions, according to which their efforts were aimed at continuous analysis of possible consequences, checking for the potential risks, economic use of their own resources by indirect actions and manipulations.

So, the results analysis demonstrates that a little more than a half of the respondents are prone to choose the constructive stress coping strategies, which confirms the necessity of correction of the intentions expressed by the second half of the surveyed.

Table 6.

Levels of regulation component of the medical students' readiness for constructive interaction with children.

\begin{tabular}{|c|c|}
\hline Levels & Amount of the surveyed \% \\
\hline low & 9.6 \\
\hline medium & 57.1 \\
\hline high & 33.3 \\
\hline
\end{tabular}

As the data of the table 6 show, only $33.3 \%$ of medical students expressed high level of psychological readiness for interaction with children. The medium level of regulation component was peculiar to $57.1 \%$ and the low level - to $9.6 \%$ of the surveyed.

The results obtained indicate most medical students' disability to choose the most appropriate behavioral pat- 
terns and strategies properly, taking into account the children's interests. They confirm the need for psychological work with students-pediatricians aimed at the correction

\section{ЛІТЕРАТУРА}

1. Вітенко І. С. Соціально-психологічний тренінг: цикл вправ для підготовки лікарів-медичних психологів : навч.-метод. посіб. / І. С. Вітенко, Т. І. Вітенко ; за ред. проф. І. С. Вітенка. - Чернівці : Книги - XXI, 2006. - 104 с.

2. Емельянов С. М. Практический гид по конфликтологии / С. М. Емельянов. - 2-е изд., перераб. СПб. : Питер, 2001. - 400 с.

3. Кобзар О. Б. Система навчального процесу в медичному вузі / О. Б. Кобзар. - К. : СТИЛОС, 1997. $242 \mathrm{c}$.

4. Методичні вказівки до практичних занять 3 медичної психології. - Чернівці : Буковинський державний медичний університет, 2007. - 50 с.

5. Райгородский Д. Я. Практическая психодиагностика. Методики и тесты : учеб. пособ. / Д. Я. Райгородский ; ред.-сост. Д. Я. Райгородский. - Самара : Бахрах, М. - 2000. - 672 c.

\section{REFERENCES}

1. Vitenko, I. S., \& Vitenko, T. I. (2006). Sotsialnopsykholohichnyi treninh [Social-psychological training]. I. S. Vitenko (Ed.). Chernivtsi: Knyhy - XXI [in Ukrainian].

2. Yemelyanov, S. M. (2001). Prakticheskiy gid po konfliktologii [Practical guide on conflict management studies]. $2^{\text {nd }}$ ed., rev. Saint Petersburg: Piter [in Russian].

3. Kobzar, O. B. (1997). Osvitnia systema $v$ medychniy shkoli [Educational system in a medical school]. Kyiv: STYLOS [in Ukrainian].

4. Metodychni vkazivky do praktychnykh zaniat z medychnoi psykholohii [Study guide on medical psychology]. (2007). Chernivtsi: Bukovinian state medical university [in Ukrainian].

5. Raigorodskiy, D. Ya. (2000). Prakticheskaya psikhodiagnostika. Metodiki i testy [Practical psychodi-

of the component of their readiness for interaction with child patients.

6. Ben-Sira Z. Affective and instrumental components in the physician-patient relationship: additional dimensions of interaction theory / Z. Ben-Sira // Journal of Health and Social Behavior. - 1980. - Vol. 21. - No.2. - P. 170.

7. Lymar L. The Basic Components of the «DoctorPatient» Constructive Interaction [Электронный pecypc] / L. Lymar // Middle East Journal of Scientific Research. Режим http://www.idosi.org/mejsr/mejsr13(sesh)13/2.pdf.

8. Thomas K. The psychodynamics of relating // Social interaction and personal relationships / K. Thomas ; ed. by D. Miell, R. Dallos. - London : Sage Publication, 1996. - P. 157-212.

9. Veatch R. The basics of bioethics / Robert Veatch. Upper Saddle River. - NJ : Prentice-Hall, 2000. $450 \mathrm{p}$.

agnostics. Techniques and tests]. Samara: Bakhrakh-M [in Russian].

6. Ben-Sira, Z. (1980). Affective and instrumental components in the physician-patient relationship: additional dimensions of interaction theory. Journal of health and social behavior, 2, 170-173. (Vols. 21) [in English].

7. Lymar, L. (2013). The basic components of the «doctor-patient» constructive interaction. Middle East journal of scientific research. Retrieved from: http://www.idosi.org/mejsr/mejsr13(sesh)13/2.pdf [in English].

8. Thomas, K. (1996). The psychodynamics of relating. D. Miell, R. Dallos (Eds.). (pp. 157-212). London: Sage Publication [in English].

9. Veatch, R. (2000). The basics of bioethics. Upper Saddle River, NJ: Prentice-Hall [in English].

Леся Володимирівна Лимар, кандидат психологічних наук, доиент кафедри іноземних мов, Київський національний медичний університет імені О. О. Богомольия, бул. Шевченка, 13, м. Київ, Украӥна

\section{ДЕЯКІ ХАРАКТЕРИСТИКИ РЕГУЛЯЩЙНОГО КОМПОНЕНТУ ГОТОВНОСТІ ДО ВЗАСМОДІЇ З ДІТЬМИ, ВИЯВЛЕНІ У ШКІЛЬНОГО МЕДИЧНОГО ПЕРСОНАЛУ}

Базові фактори успішної роботи шкільного медичного персоналу включають не лише виконання лікувальної та профілактичної роботи, але, перш за все, встановлення емоційного контакту з дітьми, який характеризує готовність лікарів і медсестер до продуктивної взаємодії. Визначення показників готовності шкільного медичного персоналу до взаємодії з пацієнтами є важливим для визначення факторів, які можуть заважати продуктивній взаємодії лікарів чи медсестер із дітьми. Необхідно визначати рівень готовності до продуктивної професійної взаємодії з пацієнтами у студентів вищих медичних навчальних закладів з метою ії корекції за необхідності на початкових етапах професійного становлення. Мета дослідження - визначити головні компоненти регуляційного компоненту готовності до взаємодії з дітьми у шкільного медичного персоналу; представити результати проведеного емпіричного дослідження розвитку цього компоненту серед медичних працівників, які працюють 3 дітьми 
у школах чи дитячих таборах з формулюванням подальших висновків і рекомендацій щодо корекції компонента, що досліджується. Для дослідження регуляційного компонента психологічної готовності медичного персоналу до професійної взаємодії з дітьми було обрано наступні методи: метод діагностики самоконтролю за М. Снайдером, метод діагностики поведінкового стилю за Т. Томасом (в адаптації Н. Грішиної), та метод С. Хобфола «Стратегії подолання стресових ситуацій». За результатами опитування 334 студентів-медиків, що навчаються у Київському національному медичному університеті імені О. О. Богомольця, лише одна третина 3 них виявила високий рівень психологічної готовності до взаємодії з дітьми за регуляційним компонентом. Середній рівень сформованості регуляційного компонента було виявлено в $57.1 \%$ студентів та низький рівень - у $9.6 \%$ опитаних. Результати дослідження свідчать про обмежені здібності гнучкого вибору оптимальних стратегій поведінки студентами-медиками, які б враховували інтереси дитини. Отримані показники обумовлюють необхідність психологічної роботи зі студентами-медиками педіатричного відділення з метою корекції компонента готовності до взаємодії з пацієнтами дитячого віку.

Ключові слова: шкільний медичний персонал, готовність, регуляція, взаємодія, діти.

Леся Владимировна Лымарь, кандидат психологических наук, дочент кафедры иностранных языков, Киевский национальный медицинский университет имени А. А. Богомольцุа, бул. Шевченко, 13, г. Киев, Украина

\section{НЕКОТОРЫЕ ХАРАКТЕРИСТИКИ РЕГУЛЯЦИОННОГО КОМПОНЕНТА ГОТОВНОСТИ К ВЗАИМОДЕЙСТВИЮ С ДЕТЬМИ, ВЫЯВЛЕННЫЕ У ШКОЛЬНОГО МЕДИЦИНСКОГО ПЕРСОНАЛА}

Основные факторы успешной работы школьного медицинского персонала включают не только выполнение лечебной и профилактической работы, но, прежде всего, установление эмоционального контакта с детьми, что характеризует готовность врачей и медсестер к продуктивному взаимодействию. Определение показателей готовности школьного медицинского персонала к взаимодействию с пациентами является важным для определения факторов, которые могут мешать продуктивному взаимодействию врачей или медсестер с детьми. Необходимо определить уровень готовности к продуктивному профессиональному взаимодействию с пациентами студентов высших медицинских учебных заведений с целью ее коррекции при необходимости на начальных этапах профессионального становления. Цель исследования - определить главные составляющие регуляционного компонента готовности к взаимодействию с детьми у школьного медицинского персонала; представить результаты проведенного эмпирического исследования развития этого компонента среди медицинских работников, работающих с детьми в школах или детских лагерях с формулировкой дальнейших выводов и рекомендаций по коррекции исследуемого компонента. Для исследования регуляционного компонента психологической готовности медицинского персонала к профессиональному взаимодействию с детьми были выбраны следующие методы: метод диагностики самоконтроля по М. Снайдеру, метод диагностики поведенческого стиля по Т. Томасу (в адаптации Н. Гришиной), и метод С. Хобфола «Стратегии преодоления стрессовых ситуаций». По результатам опроса 334 студентов-медиков, обучающихся в Киевском национальном медицинском университете имени А. А. Богомольца, только одна треть из них проявила высокий уровень психологической готовности к взаимодействию с детьми согласно регуляционному компоненту. Средний уровень сформированности регуляционного компонента был обнаружен у $57.1 \%$ студентов и низкий уровень - у 9.6\% опрошенных. Результаты исследования свидетельствуют об ограниченных способностях гибкого выбора оптимальных стратегий поведения студентами-медиками, которые бы учитывали интересы ребенка. Полученные показатели обусловливают необходимость психологической работы со студентами-медиками педиатрического отделения с целью коррекции компонента их готовности ко взаимодействию с пациентами детского возраста.

Ключевые слова: школьный медицинский персонал, готовность, регуляция, взаимодействие, дети.

Подано до редакиії 01.09.2016 